\title{
The protective effects of the melanocortin receptor (MCR) agonist, melanotan-II (MTII), against binge-like ethanol drinking are facilitated by deletion of the MC3 receptor in mice
}

\author{
J.J. Olney, M.A. ${ }^{1}$, G.M. Sprow, Ph.D. ${ }^{1}$, M. Navarro, Ph.D. ${ }^{1}$, and T.E. Thiele, Ph.D. ${ }^{1,2}$ \\ ${ }^{1}$ Department of Psychology, University of North Carolina, Chapel Hill, NC, USA \\ ${ }^{2}$ Bowles Center for Alcohol Studies, University of North Carolina, Chapel Hill, NC, USA
}

\begin{abstract}
Recent data have implicated the melanocortin (MC) system in modulating voluntary ethanol consumption. Administration of melanotan-II (MTII), a nonselective melanocortin receptor (MCR) agonist, reduces voluntary ethanol consumption in C57BL/6J mice. Previous studies have demonstrated that central infusion of MTII effectively reduced voluntary ethanol drinking in mutant mice lacking normal expression of $\mathrm{MC} 3 \mathrm{R}\left(\mathrm{MC}^{2} \mathrm{R}^{-/-}\right.$mice) but failed to alter ethanol drinking in mice lacking expression of MC4R, demonstrating that central MTII administration reduces voluntary ethanol drinking by signaling through the MC4R. However, evidence shows that the neurocircuitry recruited during excessive binge-like ethanol drinking versus moderate ethanol drinking are not identical. Thus the present study sought to investigate the potential role of the MC3R in binge-like ethanol intake. To this end, the "drinking in the dark" (DID) procedure, a commonly used animal model of binge-like ethanol drinking, was employed. Wild-type MC3R $\mathrm{R}^{+/+}$ and $\mathrm{MC}^{-1 /-}$ mice were given intracerebroventricular (i.c.v.) infusion of MTII $(0.0,0.25,0.50$, or $1.0 \mu \mathrm{g}$ ) prior to the onset of a four-hour testing period in which mice were given access to $20 \%$ (v/ v) ethanol. Immediately after the four-hour testing period, tail blood samples were collected from each animal in order to assess blood ethanol concentrations (BECs). Consistent with previous findings, central administration of MTII blunted binge-like ethanol drinking in both $\mathrm{MC}^{3} \mathrm{R}^{+/+}$and $\mathrm{MC} \mathrm{R}^{-/-}$mice. Interestingly, all doses of MTII blunted binge-like ethanol drinking in $\mathrm{MC}^{-1-}$ mice during the first hour of testing, while only the $1.0 \mu \mathrm{g}$ dose reduced binge-like drinking in $\mathrm{MC} \mathrm{R}^{+/+}$mice. Thus, $\mathrm{MC} 3 \mathrm{R}^{-/-}$mice were more sensitive to the protective effects of MTII. These data suggest that MC3Rs oppose the protective effects of MTII against binge-like ethanol drinking, and thus selective MC3R antagonists may have potential therapeutic roles in treating excessive ethanol drinking.
\end{abstract}

\section{Keywords}

Melanocortin; MC3 receptor; binge-like drinking; MTII; ethanol

(C) 2013 Elsevier Ltd. All rights reserved

Corresponding author: Todd E. Thiele, Ph.D. Department of Psychology University of North Carolina Davie Hall, CB \#3270 Chapel Hill, NC 27599-3270, USA Phone: 919-966-1519 Fax: 919-962-2537 thiele@unc.edu.

Publisher's Disclaimer: This is a PDF file of an unedited manuscript that has been accepted for publication. As a service to our customers we are providing this early version of the manuscript. The manuscript will undergo copyediting, typesetting, and review of the resulting proof before it is published in its final citable form. Please note that during the production process errors may be discovered which could affect the content, and all legal disclaimers that apply to the journal pertain. 


\section{Introduction}

The melanocortin (MC) peptides, $\alpha-, \beta-, \gamma$ - melanocyte stimulating hormone (MSH), and adrenocorticotropic hormone (ACTH), are produced centrally by proopiomelanocortin (POMC)-expressing neurons within the arcuate nucleus of the hypothalamus, the nucleus of the solitary tract, and medulla (Jacobowitz and O'Donohue, 1978). These peptides, as well as their endogenous antagonists, agouti and agouti-related protein (AgRP), act through five seven-transmembrane G-protein coupled melanocortin receptor (MCR) subtypes. The MCRs within the rodent brain are predominantly comprised of the MC3R and MC4R subtypes, while MC1R, MC2R, and MC5R are expressed primarily in the periphery (Adan and Gispen, 1997; Barrett et al., 1994; Xia et al., 1995). Together, these ligands and their associated receptors, collectively referred to as the MC system, regulate a myriad of physiological functions including pigmentation (Robbins et al., 1993), sexual function (Argiolas et al., 2000), and appetite regulation (Fan et al., 1997; Giraudo et al., 1998), among others.

A growing body of literature has also implicated MCR signaling in modulating ethanol consumption. This association was first uncovered when it was reported that ethanol naïve alcohol preferring rats displayed abnormal expression of MC3R and MC4R within the nucleus accumbens and hypothalamus relative to their non-preferring counterparts (Lindblom et al., 2002). Extending on these findings, it was later demonstrated that central infusion of a nonselective MCR agonist, melanotan-II (MTII), attenuated voluntary ethanol consumption in these preferring rats (Ploj et al., 2002). Furthermore, central infusion of MTII reduced voluntary ethanol drinking in both wild-type and mutant mice deficient in MC3R, suggesting that the MC3R does not modulate voluntary drinking (Navarro et al., 2005). What is more, Navarro and colleagues also showed that a selective MC4R agonist blunted voluntary ethanol consumption in wild-type C57BL/6J mice, implicating the MC4R in modulating ethanol intake (Navarro et al., 2003). Consistent with these findings, later work revealed that MTII had no effect on voluntary ethanol consumption in mutant mice lacking MC4R (Navarro et al., 2011). Taken together, these data suggest that central MTII reduces voluntary ethanol drinking by signaling through the MC4R, but not the MC3R.

However, previous findings have implicated that the MC3R regulates the transmission of aMSH from POMC neurons. Specifically, the MC3R has been found to be expressed on POMC neurons (Bagnol et al., 1999), suggesting that it functions as an autoreceptor. Subsequent in vitro investigations revealed that activation of these receptors using the

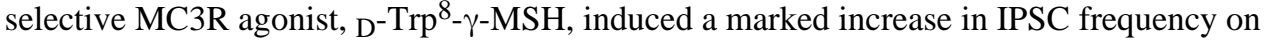
POMC neurons (Cowley et al., 2001). Additionally, central infusions of this same compound caused a downregulation of POMC mRNA levels in rats (Lee et al., 2008). What is more, rats receiving intracerebroventricular (i.c.v.) infusions of an MC3R agonist displayed increased food intake, while low doses of an MC3R antagonist reduced food intake (Lee et al., 2008). Together, these studies provide converging evidence that indicate the MC3R serves as an inhibitory autoreceptor on POMC neurons.

Additionally, recent converging evidence has suggested that different neurocircuitry modulates moderate level ethanol drinking versus excessive binge-like ethanol drinking (Lowery et al., 2010; Lowery-Gionta et al., 2012; Sparta et al., 2008). Despite the growing body of literature implicating the $\mathrm{MC}$ system in voluntary ethanol consumption, the role of the MC system in binge-like ethanol consumption remains relatively unexplored. We recently showed that mutant mice lacking AgRP exhibited blunted binge-like ethanol drinking, providing initial evidence that MCR signaling modulates binge-like drinking (Navarro et al., 2009). To further characterize the role of MC system in binge-like ethanol drinking, we employed "drinking in the dark" (DID) procedures and used mutant mice 


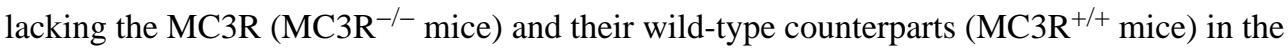
current study to determine the potential contribution of the MC3R in modulating the protective effects of MTII against binge-like ethanol drinking. Consistent with the previous data (Navarro et al., 2005), we found that infusions of MTII attenuated binge-like ethanol consumption in both $\mathrm{MC} \mathrm{R}^{+/+}$and $\mathrm{MC} 3 \mathrm{R}^{-/-}$mice. However, we observed that MTII was more effective in reducing binge-like ethanol drinking in $\mathrm{MC}^{-1 /-}$ relative to $\mathrm{MC}^{-1 /+}$ mice. These data suggest that MC3Rs oppose the protective effects of MTII against bingelike ethanol drinking, and thus selective MC3R antagonists may have potential therapeutic value in treating excessive ethanol drinking.

\section{Materials and methods}

\subsection{Animals}

The generation of $\mathrm{MC}^{-1-}$ has been described previously (Chen et al., 2000). Sixteen littermate knockout $\left(\mathrm{MC} \mathrm{R}^{-/-}\right)$and ten wild-type $\left(\mathrm{MC} \mathrm{R}^{+/+}\right)$mice maintained on a C57BL/ $6 \mathrm{~J}$ background were bred in-house from heterozygous stock. Genotype was determined via polymerase chain reaction (PCR). All mice were housed in individual home cages located in a vivarium with an ambient temperature of approximately $22^{\circ} \mathrm{C}$ and a $12: 12 \mathrm{~h}$ reverse light/ dark cycle with lights off at 7:00am. Food and water were available ad libitum except where indicated below. It has previously been demonstrated that compounds targeting MCRs exhibit similar effects on ethanol intake in male and female mice (Navarro et al., 2005); therefore, both sexes were included in the present study in an effort to increase sample sizes. All procedures in this study were in compliance with the National Institute of Health guidelines, and all protocols were approved by the University of North Carolina Institutional Animal Care and Use Committee.

\subsection{Cannulation Surgery and Infusion Procedure}

Prior to testing, mice underwent cannulation surgery targeting the left lateral ventricle, which has been described previously (Navarro et al., 2011, 2005, 2003). Following surgery, mice were given approximately one week to recover before testing. Following completion of testing, cannula placement was verified histologically. All mice in the current study were found to have accurate placement; thus no animals were excluded from the analysis due to poor cannula placement. The non-selective MCR agonist melanotan-II (MTII; American Peptide Company, Sunnyvale, CA) was dissolved in $0.9 \%$ saline to reach the desired concentration $(0.0,0.25,0.5$, or $1.0 \mu \mathrm{g})$. A non-selective, rather than selective, MCR compound was chosen for this study in order to elucidate the potential interaction of the MC3R and MC4R in modulating the effects of a MCR agonist on binge-like ethanol drinking behavior. All doses were infused in a $1.0 \mu \mathrm{l}$ volume using a Hamilton syringe (Hamilton Company USA, Reno, NV), which was administered manually over the course of one minute. This injector was left in place for an extra 30 seconds to allow for diffusion and to prevent reflux of the compound up the cannula tract. Following the infusion, mice were returned to their homecages.

\section{3. "Drinking in the dark" procedures}

A four day DID procedure was used to model binge-like ethanol drinking (Rhodes et al., 2005). It has previously been shown that mice in this paradigm are able to achieve a blood ethanol concentrations (BECs) that surpass the $80 \mathrm{mg} / \mathrm{dl}$ criterion used by the National Institute on Alcohol Abuse and Alcoholism to define an episode of binge drinking (National Institute on Alcohol Abuse and Alcoholism, 2004; Rhodes et al., 2007) and that drinking using this method is likely not motivated by caloric need (Lyons et al., 2008). For the first three days of DID, MC3R $\mathrm{R}^{+/+}$and MC3R $\mathrm{R}^{-/-}$mice were weighed and given mock infusions at the beginning of the dark cycle in order to acclimate the animals to the infusion procedure. 
Using standard DID procedures outlined by Rhodes and colleagues (2005), water bottles were removed three hours into the dark cycle and replaced with a single bottle of ethanol $(20 \% \mathrm{v} / \mathrm{v})$ for two hours. Water bottles were returned to the mice at the end of each day of testing. Treatment groups were equated based on ethanol consumption on days $1-3$. On the fourth day of DID, mice were infused with a $0.0,0.25,0.5$ or $1.0 \mu \mathrm{g}$ dose of MTII as described above. Although it has previously been reported to have a relatively short half-life (Ugwu et al., 1994) in rats, the detailed pharmacokinetics of MTII have yet to be explored in mice. Nonetheless, previous studies have demonstrated that its effects on ethanol consumption persist for several hours following initial administration. For example, Navarro and colleagues (2003) observed that a single injection of MTII blunted ethanol drinking as long as eight hours post-injection. Binge-like ethanol consumption was assessed on this fourth day of testing, which followed the same schedule as the first three days with the exception that ethanol access was extended to four hours. $\mathrm{MC}^{+} \mathrm{R}^{+/+}$and $\mathrm{MC} \mathrm{R}^{-/-}$mice were given i.c.v. infusions of MTII two hours before ethanol access. Consumption measures were collected at the first hour of ethanol access as well as at the end of the four hours of testing in order to measure the immediate and prolonged effects of the drug on ethanol intake, respectively. Tail bloods were collected from each animal at the end of the four-hour testing period in order to determine BECs using an alcohol analyzer (Analox Instruments, Lunenburg, MA). Mice were given at least three days of rest between subsequent 4-day DID sessions in order to avoid carryover effects of the drug. A Latin square design was utilized such that the animals received each dose (vehicle, $0.25,0.5$, and $1.0 \mu \mathrm{g}$ of MTII) in a counterbalanced order.

\subsection{Statistical analysis}

A repeated measures ANOVA was used to analyze consumption and BEC data, with dose of $\operatorname{MTII}(0,0.25,0.5$, or $1.0 \mu \mathrm{g})$ as the within-subject variable and genotype $\left(\mathrm{MC} \mathrm{R}^{-/-}\right.$and $\mathrm{MC} \mathrm{R}^{+/+}$) as the between-subject variable. The tail blood samples from three $\mathrm{MC}^{2} \mathrm{R}^{-/-}$ mice were lost during centrifugation and were eliminated from BEC analysis. Importantly, the central issue regarding the role of the MC3R in modulating the protective effects of MTII against binge-like ethanol drinking was directly assessed using planned comparisons (Cohen, 2008) based on a priori predictions stemming from previous observations. Specifically, given the previous research indicating that MTII blunts ethanol drinking (Navarro et al., 2011, 2005, 2003; Ploj et al., 2002) coupled with the implications that the MC3R serves as an inhibitory autoreceptor on POMC neurons (Bagnol et al., 1999; Cowley et al., 2001; Lee et al., 2008; Marks et al., 2006), we predicted that MTII would dosedependently blunt binge-like ethanol drinking and that this effect would be more robust in $\mathrm{MC} \mathrm{R}^{-/-}$mice since a lack of presynaptic autoreceptors would protect against MTIIinduced inhibition of POMC neurons. Thus, planned comparisons were performed using paired-sample t-tests to directly assess the effect of each dose of MTII $(0.25,0.5$, or $1.0 \mu \mathrm{g})$ versus vehicle treatment within each genotype. Additionally, Bonferroni corrections were used with planned comparisons to control for inflation of Type I error rate associated with multiple tests. Finally, a Pearson correlation was performed to examine the relationship between ethanol consumed over the four hour test and BECs collected immediately after ethanol testing.

\section{Results}

\subsection{Effect of MTII on the first hour of binge-like ethanol drinking}

Repeated measures ANOVA revealed that binge-like ethanol consumption during the first hour of testing was similar between $\mathrm{MC} 3 \mathrm{R}^{+/+}$and $\mathrm{MC}^{-1-}$ mice (main effect of genotype: $F(1,24)=1.499, p=0.233$; Fig. 1A). Relative to vehicle, central infusions of MTII significantly reduced binge-like ethanol consumption during the first hour of testing among 


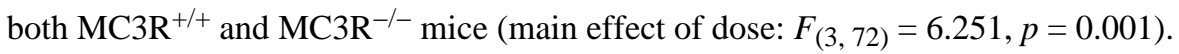
Specifically, ethanol drinking was significantly reduced in mice treated with the highest dose of MTII $(1.0 \mu \mathrm{g})$ relative to vehicle $(p<.001)$. No significant interaction was observed during the first hour (genotype $\times$ dose interaction: $F_{(3,72)}=0.993, p=0.401$ ). Interestingly, among $\mathrm{MC} \mathrm{R}^{-/-}$mice, planned comparisons revealed that, relative to vehicle, all doses $(0.25,0.5$, and $1.0 \mu \mathrm{g})$ of MTII were effective in reducing ethanol intake during the first hour $\left(t_{(1,15)}=3.039, p=0.008 ; t_{(1,15)}=4.128, p=0.001 ; t_{(1,15)}=3.610, p=0.003\right.$;

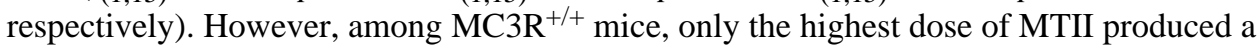
significant reduction in ethanol drinking $\left(t_{(1,9)}=3.559, p=0.006\right)$.

\subsection{Effect of MTII on four hours of binge-like ethanol drinking}

Binge-like ethanol consumption between $\mathrm{MC} 3 \mathrm{R}^{+/+}$and $\mathrm{MC} \mathrm{R}^{-/-}$was not significantly different at the end of the four hour test period (main effect of genotype: $F_{(1,24)}=1.245, p=$ 0.276 ; Fig. 1B). Treatment with MTII elicited a significant decrease in ethanol drinking across the four hours regardless of genotype (main effect of dose: $F_{(3,72)}=5.594, p=$ $0.002)$. Further examination revealed ethanol drinking was significantly reduced following treatment with the highest dose of MTII $(p=0.002)$. No significant interaction effect was observed at the end of the four hour test period (genotype $\times$ dose interaction: $F_{(3,72)}=$ $0.813, p=0.491)$. However, planned comparisons revealed that the significant reduction in ethanol intake in $\mathrm{MC} \mathrm{R}^{-/}$mice treated with the highest dose of MTII persisted across the four hour test period $\left(t_{(1,15)}=3.218, p=0.006\right)$.

\subsection{Effect of MTII on BEC}

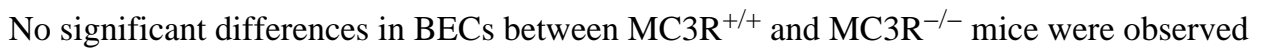
following DID testing (main effect of genotype: $F_{(1,21)}=0.126, p=0.726$; Fig. $1 \mathrm{C}$ ). There was a trend for an effect of dose of MTII on measured BECs, but this effect was not significant (main effect of dose: $F_{(3,63)}=2.549, p=0.064$ ). No significant interaction was observed in measured BECs (genotype $\times$ dose interaction: $F_{(3,63)}=0.812, p=0.492$ ). Further analysis of the planned comparisons yielded no significant differences in either genotype at any of the doses tested relative to the vehicle condition. Although these analyses revealed no significant differences in BEC as a result of drug treatment, there was a strong, positive relationship between $\mathrm{BEC}$ and ethanol consumed over the four hour period for both

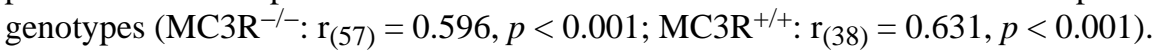

\section{Discussion}

These studies examined the central actions of the nonselective MCR agonist MTII, on binge-like ethanol drinking in $\mathrm{MC}^{-/-}$and wild-type $\mathrm{MC}^{-/+}$mice. Overall, the present results confirmed previous findings showing that centrally administered MTII attenuates ethanol consumption (Navarro et al., 2011, 2005, 2003). The observations made here add to the literature by showing that central administration of MTII also results in a decrease in binge-like ethanol intake in both $\mathrm{MC}^{-/-}$and $\mathrm{MC}^{-1 /+}$ mice. Importantly, we observed that mice with normal expression of MC3R were less sensitive to the protective effects of MTII against binge-like ethanol drinking relative to mice deficient of MC3R. This report, to the best of our knowledge, provides the first evidence that the MC3R modulates the actions of centrally administered MTII on binge-like ethanol drinking.

One could argue that the increased sensitivity observed in $\mathrm{MC}^{-1-} \mathrm{R}^{--}$mice is due to the fact that the removal of MC3Rs may allow for a greater proportion of MTII to interact with MC4Rs. While we cannot completely rule out this possibility, MTII is known to be a highly potent MC receptor agonist (Dorr et al., 1996); as such, the effects of increased binding of MTII to MC4R in MC3R $\mathrm{R}^{-/}$mice might be expected to be negligible. 
A more likely explanation for this phenomenon is that the MC3R acts as an inhibitory autoreceptor on POMC neurons. Previous studies have already identified MC3R as being expressed on POMC neurons (Bagnol et al., 1999). What is more, data from electrophysiological, immunohistochemistry, and behavioral studies report decreased activity in POMC neurons following selective activation of MC3Rs (Cowley et al., 2001; Lee et al., 2008; Marks et al., 2006). Although AgRP neurons within the arcuate nucleus express MC3R (Bagnol et al., 1999), it has previously been demonstrated that central administrations of a selective MC3R agonist suppresses levels of POMC mRNA expression but has no effect on AgRP gene expression (Lee et al., 2008). Together, these studies reinforce the idea that the MC3R acts as an inhibitory autoreceptor on the POMC circuit, likely inhibiting transmission of a-MSH from POMC neurons. Thus, in the absence of the MC3R, both MTII and endogenous a-MSH participate in tandem to reduce binge-like ethanol drinking, while activation of the MC3R by MTII counteracts this process in wildtype mice by inhibiting the release of endogenous a-MSH. A second possibility is that the MC3R, in some circuits, exists as a postsynaptic receptor and functionally opposes the downstream actions of MC4R signaling. The observation that genetic deletion of MC3R produces a mouse that is more susceptible to the attenuating effects of MTII on binge-like ethanol drinking is consistent with either a presynaptic autoreceptor or a postsynaptic receptor that functionally opposes the actions of the MC4R. In terms of the current study, both genotypes displayed reductions in binge-like ethanol drinking in response to MTII since the intact MC4R of both genotypes was able to blunt ethanol drinking- a finding that is consistent with the previous literature (Navarro et al., 2011, 2005). Importantly, MC3R $\mathrm{R}^{-/-}$ mice showed increased sensitivity to the protective effects of MTII (i.e. significant reductions in drinking were observed in lower doses of MTII in these mice relative to $\mathrm{MC} \mathrm{R}^{+/+}$) as the oppositional MC3R was removed and MC4R was free to function unimpeded.

The fact that no differences were found in BECs between vehicle-treated and MTII-treated mice may be related to the time course of each animal's drinking. Specifically, tail blood samples were collected only at the end of the 4-hour test. As such, drinking that occurs toward the beginning of the test session may be less influential on the measured BEC than drinking that occurs more towards the end of the session. This is especially likely considering the rather rapid decline of BEC that is characteristic of mice (Livey et al., 2003). As the protective effects of MTII on ethanol intake were most evident at the beginning of the 4-hour test, it seems likely that increased consumption later in the 4-hour test session may have masked the effects of MTII treatment on BECs. In this sense, tail blood samples collected after the first hour may have provided a more accurate assessment of an animal's BEC. However, taking tail bloods for BEC assessment is a stressful experience for the animal that involves restraining the mouse and nicking its tail to obtain a blood sample to be analyzed. Moreover, previous studies have reported that stressful stimuli can alter drinking behavior (Nash and Maickel, 1985; Rockman et al., 1986); therefore, tail bloods were only collected after ethanol bottles were removed in order to avoid submitting the animals to undue stress during testing, which could have confounded the drinking data. Importantly, although no differences were found in BECs between treatment conditions, there was a strong, direct correlational relationship between the amount ethanol consumed and the measured BECs for both genotypes.

It may be surprising that the observations made here differ from previous studies examining the role of the MC3R in ethanol drinking, which found no significant contribution of the MC3R on ethanol drinking (Navarro et al., 2005). However, two key differences between the two studies that may account for this. First, the previous study measured 24-hour voluntary ethanol consumption while the present experiment utilized the limited access DID procedure to model binge-like ethanol consumption. Previous studies have reported that 
separate neurocircuits may be involved in voluntary versus binge consumption. For example, voluntary consumption engages the reward pathway (Koob et al., 1998; Volkow and $\mathrm{Li}, 2004$ ) while binge consumption likely recruits stress circuits (Koob, 2008; LoweryGionta et al., 2012; Sparta et al., 2008) in addition to the reward pathway. Thus, it is possible that MC3Rs are involved in the modulation of excessive binge-like ethanol drinking but not moderate levels of ethanol intake that are characteristic of voluntary ethanol consumption procedures. More importantly, our study used multiple doses $(0.25,0.5$ and 1.0 $\mu \mathrm{g})$ of MTII while only one dose $(1.0 \mu \mathrm{g})$ was used previously. Even in the current report, genotype differences in MTII sensitivity could have easily missed been as the highest dose of MTII blunted binge-like ethanol drinking in both genotypes, at least at the 1-hour measure (Fig. 1A). It is not until all of the doses of MTII are taken into account that a pattern emerges that indicates loss of the MC3R augments the protective effects of MTII.

Given the involvement of the MC system in feeding behavior, these data further underscore the overlapping pathways involved in alcohol and food consumption. Indeed, it has previously been demonstrated that, in addition to suppressing alcohol consumption, treatment with centrally-administered MTII in doses used here $(0.5$ or $1.0 \mu \mathrm{g})$ also reduced the consumption of food, sucrose solution (caloric reinforcers) and saccharin solution (a salient non-caloric reinforcer), but not water drinking (Navarro et al., 2005; 2011). These observations are consistent with the idea that the central MC system modulates the consumption of natural reinforcers (food and sweet solutions) and ethanol, regardless of caloric content. Moreover, a wealth of neurochemical systems involved in both alcohol and food consumption have already been identified (See Thiele et al., 2003 for review). A multitude of clinical reports have described a relatively high rate of co-morbidity between alcohol abuse and eating disorders (Dansky et al., 2000; Higuchi et al., 1993; Holderness et al., 1994), which is not surprising considering both conditions involve aberrant consummatory behavior and a loss of control. Moreover, in patients presenting both alcoholism and eating disorders, it is often found that successful treatment of one disorder also proves to be efficacious to both conditions (Daniels et al., 1999; Dawe and Staiger, 1998). Given these circumstances, examination of therapeutic drugs that act on these shared neurochemical systems, such as the melanocortin system, may prove to be a worthwhile endeavor.

\section{Conclusions}

In summary, we have demonstrated a possible role for the MC3R in modulating binge-like ethanol consumption. Specifically, the MC3R appears to oppose the protective effects of MTII against binge-like ethanol drinking, which may indicate that the MC3R serves as an autoreceptor that prevents the release of endogenous a-MSH, or as a postsynaptic receptor that functionally opposes the downstream actions of the MC4R. It will be important for future studies to further characterize the contribution of the MC3R in modulating ethanol consumption. The current observations suggest that MC3R antagonists may have therapeutic value in combating alcohol abuse disorders, and may augment the ability of MC4R agonists to protect against binge drinking.

\section{Acknowledgments}

Sources of support: This work was supported by National Institute of Health grants AA019839, AA013573, and AA015148 and Department of Defense grant W81XWH-09-1-0293.

\section{References}

Adan RA, Gispen WH. Brain melanocortin receptors: from cloning to function. Peptides. 1997; 18:1279-1287. [PubMed: 9396074] 
Argiolas A, Melis MR, Murgia S, Schiöth HB. ACTH- and alpha-MSH-induced grooming, stretching, yawning and penile erection in male rats: site of action in the brain and role of melanocortin receptors. Brain Res. Bull. 2000; 51:425-431. [PubMed: 10715564]

Bagnol D, Lu XY, Kaelin CB, Day HE, Ollmann M, Gantz I, Akil H, Barsh GS, Watson SJ. Anatomy of an endogenous antagonist: relationship between Agouti-related protein and proopiomelanocortin in brain. J. Neurosci. 1999; 19:RC26. [PubMed: 10479719]

Barrett P, MacDonald A, Helliwell R, Davidson G, Morgan P. Cloning and expression of a new member of the melanocyte-stimulating hormone receptor family. J. Mol. Endocrinol. 1994; 12:203213. [PubMed: 8060485]

Chen AS, Marsh DJ, Trumbauer ME, Frazier EG, Guan XM, Yu H, Rosenblum CI, Vongs A, Feng Y, Cao L, Metzger JM, Strack AM, Camacho RE, Mellin TN, Nunes CN, Min W, Fisher J, GopalTruter S, MacIntyre DE, Chen HY, Van der Ploeg LH. Inactivation of the mouse melanocortin-3 receptor results in increased fat mass and reduced lean body mass. Nat. Genet. 2000; 26:97-102. [PubMed: 10973258]

Cohen, BH. Explaining psychological statistics. John Wiley; Hoboken, N.J.: 2008.

Cowley MA, Smart JL, Rubinstein M, Cerdán MG, Diano S, Horvath TL, Cone RD, Low MJ. Leptin activates anorexigenic POMC neurons through a neural network in the arcuate nucleus. Nature. 2001; 411:480-484. [PubMed: 11373681]

Daniels ES, Masheb RM, Berman RM, Mickley D, Grilo CM. Bulimia nervosa and alcohol dependence. A case report of a patient enrolled in a randomized controlled clinical trial. J Subst Abuse Treat. 1999; 17:163-166. [PubMed: 10435265]

Dansky BS, Brewerton TD, Kilpatrick DG. Comorbidity of bulimia nervosa and alcohol use disorders: results from the National Women's Study. Int J Eat Disord. 2000; 27:180-190. [PubMed: 10657891]

Dawe S, Staiger P. Case report: treatment of a woman with alcohol and binge eating problems. J Behav Ther Exp Psychiatry. 1998; 29:249-260. [PubMed: 9847044]

Dorr RT, Lines R, Levine N, Brooks C, Xiang L, Hruby VJ, Hadley ME. Evaluation of melanotan-II, a superpotent cyclic melanotropic peptide in a pilot phase-I clinical study. Life Sci. 1996; 58:17771784. [PubMed: 8637402]

Fan W, Boston BA, Kesterson RA, Hruby VJ, Cone RD. Role of melanocortinergic neurons in feeding and the agouti obesity syndrome. Nature. 1997; 385:165-168. [PubMed: 8990120]

Giraudo SQ, Billington CJ, Levine AS. Feeding effects of hypothalamic injection of melanocortin 4 receptor ligands. Brain Res. 1998; 809:302-306. [PubMed: 9853124]

Higuchi S, Suzuki K, Yamada K, Parrish K, Kono H. Alcoholics with eating disorders: prevalence and clinical course. A study from Japan. Br J Psychiatry. 1993; 162:403-406. [PubMed: 8141860]

Holderness CC, Brooks-Gunn J, Warren MP. Co-morbidity of eating disorders and substance abuse review of the literature. Int J Eat Disord. 1994; 16:1-34. [PubMed: 7920577]

Jacobowitz DM, O'Donohue TL. alpha-Melanocyte stimulating hormone: immunohistochemical identification and mapping in neurons of rat brain. Proc. Natl. Acad. Sci. U.S.A. 1978; 75:63006304. [PubMed: 366617]

Koob GF. A role for brain stress systems in addiction. Neuron. 2008; 59:11-34. [PubMed: 18614026]

Koob GF, Roberts AJ, Schulteis G, Parsons LH, Heyser CJ, Hyytiä P, Merlo-Pich E, Weiss F. Neurocircuitry targets in ethanol reward and dependence. Alcohol. Clin. Exp. Res. 1998; 22:3-9. [PubMed: 9514280]

Lee M, Kim A, Conwell IM, Hruby V, Mayorov A, Cai M, Wardlaw SL. Effects of selective modulation of the central melanocortin-3-receptor on food intake and hypothalamic POMC expression. Peptides. 2008; 29:440-447. [PubMed: 18155809]

Lindblom J, Wikberg JES, Bergström L. Alcohol-preferring AA rats show a derangement in their central melanocortin signalling system. Pharmacol. Biochem. Behav. 2002; 72:491-496. [PubMed: 11900824]

Lowery EG, Spanos M, Navarro M, Lyons AM, Hodge CW, Thiele TE. CRF-1 antagonist and CRF-2 agonist decrease binge-like ethanol drinking in C57BL/6J mice independent of the HPA axis. Neuropsychopharmacology. 2010; 35:1241-1252. [PubMed: 20130533] 
Lowery-Gionta EG, Navarro M, Li C, Pleil KE, Rinker JA, Cox BR, Sprow GM, Kash TL, Thiele TE. Corticotropin releasing factor signaling in the central amygdala is recruited during binge-like ethanol consumption in C57BL/6J mice. J. Neurosci. 2012; 32:3405-3413. [PubMed: 22399763]

Lyons AM, Lowery EG, Sparta DR, Thiele TE. Effects of food availability and administration of orexigenic and anorectic agents on elevated ethanol drinking associated with drinking in the dark procedures. Alcohol. Clin. Exp. Res. 2008; 32:1962-1968. [PubMed: 18782340]

Marks DL, Hruby V, Brookhart G, Cone RD. The regulation of food intake by selective stimulation of the type 3 melanocortin receptor (MC3R). Peptides. 2006; 27:259-264. [PubMed: 16274853]

Nash JF Jr, Maickel RP. Stress-induced consumption of ethanol by rats. Life Sci. 1985; 37:757-765. [PubMed: 4021738]

Navarro M, Cubero I, Chen AS, Chen HY, Knapp DJ, Breese GR, Marsh DJ, Thiele TE. Effects of Melanocortin Receptor Activation and Blockade on Ethanol Intake: A Possible Role for the Melanocortin-4 Receptor. Alcoholism: Clinical and Experimental Research. 2005; 29:949-957.

Navarro M, Cubero I, Knapp DJ, Thiele TE. MTII-induced reduction of voluntary ethanol drinking is blocked by pretreatment with AgRP-(83-132). Neuropeptides. 2003; 37:338-344. [PubMed: 14698676]

Navarro M, Cubero I, Ko L, Thiele TE. Deletion of agouti-related protein blunts ethanol selfadministration and binge-like drinking in mice. Genes Brain Behav. 2009; 8:450-458. [PubMed: 19566712]

Navarro M, Lerma-Cabrera JM, Carvajal F, Lowery EG, Cubero I, Thiele TE. Assessment of Voluntary Ethanol Consumption and the Effects of a Melanocortin (MC) Receptor Agonist on Ethanol Intake in Mutant C57BL/6J Mice Lacking the MC-4 Receptor. Alcoholism: Clinical and Experimental Research. 2011; 35:1058-1066.

National Institute on Alcohol Abuse and Alcoholism. NIAAA council approves definition of binge drinking. NIAAA Newsletter. 2004; 3:3.

Ploj K, Roman E, Kask A, Hyytiä P, Schiöth HB, Wikberg JES, Nylander I. Effects of melanocortin receptor ligands on ethanol intake and opioid peptide levels in alcohol-preferring AA rats. Brain research bulletin. 2002; 59:97-104. [PubMed: 12379439]

Rhodes JS, Best K, Belknap JK, Finn DA, Crabbe JC. Evaluation of a simple model of ethanol drinking to intoxication in C57BL/6J mice. Physiology \& behavior. 2005; 84:53-63. [PubMed: 15642607]

Rhodes JS, Ford MM, Yu C-H, Brown LL, Finn DA, Garland T Jr, Crabbe JC. Mouse inbred strain differences in ethanol drinking to intoxication. Genes Brain Behav. 2007; 6:1-18. [PubMed: 17233637]

Robbins LS, Nadeau JH, Johnson KR, Kelly MA, Roselli-Rehfuss L, Baack E, Mountjoy KG, Cone RD. Pigmentation phenotypes of variant extension locus alleles result from point mutations that alter MSH receptor function. Cell. 1993; 72:827-834. [PubMed: 8458079]

Rockman GE, Hall A, Glavin GB. Effects of restraint stress on voluntary ethanol intake and ulcer proliferation in rats. Pharmacol. Biochem. Behav. 1986; 25:1083-1087. [PubMed: 3786361]

Sparta DR, Sparrow AM, Lowery EG, Fee JR, Knapp DJ, Thiele TE. Blockade of the corticotropin releasing factor type 1 receptor attenuates elevated ethanol drinking associated with drinking in the dark procedures. Alcohol. Clin. Exp. Res. 2008; 32:259-265. [PubMed: 18162072]

Thiele TE, Navarro M, Sparta DR, Fee JR, Knapp DJ, Cubero I. Alcoholism and obesity: overlapping neuropeptide pathways? Neuropeptides. 2003; 37:321-337. [PubMed: 14698675]

Ugwu SO, Blanchard J, Nguyen LD, Hadley ME, Dorr RT. A comparison of HPLC and bioassay methods for plasma melanotan-II (MT-II) determination: application to a pharmacokinetic study in rats. Biopharm Drug Dispos. 1994; 15:383-390. [PubMed: 7981427]

Volkow ND, Li T-K. Drug addiction: the neurobiology of behaviour gone awry. Nat. Rev. Neurosci. 2004; 5:963-970. [PubMed: 15550951]

Xia Y, Wikberg JE, Chhajlani V. Expression of melanocortin 1 receptor in periaqueductal gray matter. Neuroreport. 1995; 6:2193-2196. [PubMed: 8595200] 

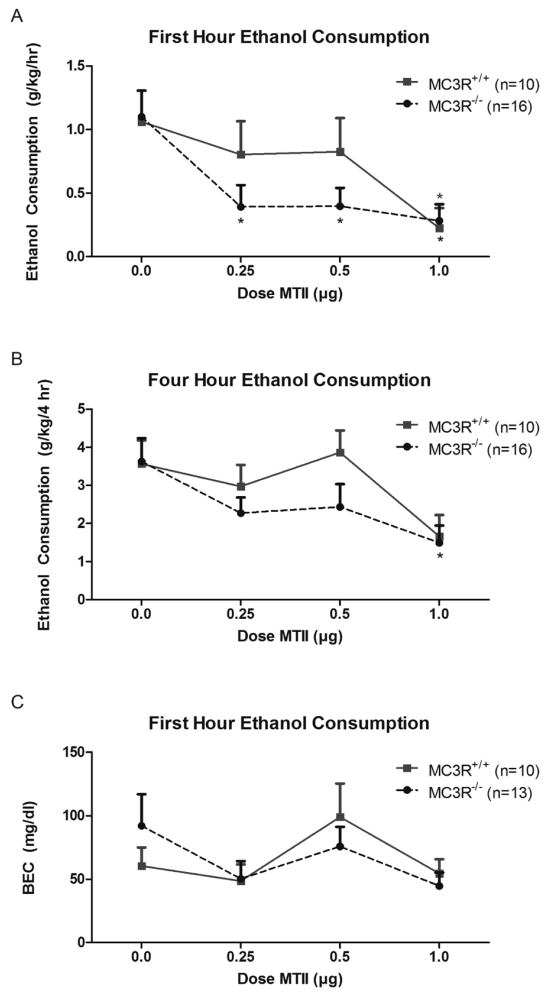

Figure 1.

Ethanol consumed $(\mathrm{g} / \mathrm{kg})$ among $\mathrm{MC} \mathrm{R}^{-/-}$and $\mathrm{MC} \mathrm{R}^{+/+}$mice during the first hour (A), and total four hours (B) of the binge-like ethanol consumption, as well as BEC (mg/dl) measured immediately at the end of the 4-hour test $(\mathrm{C})$. During the first hour, $\mathrm{MC} \mathrm{R}^{-/-}$mice displayed a reduction in binge-like ethanol drinking at all doses tested. Alternatively, significant reductions in drinking were only observed following treatment with the highest dose $(1.0 \mu \mathrm{g})$ of MTII in MC $3^{+/+}$mice. Similarly, at the end of the 4-hour test, only the highest dose of MTII caused a reduction in binge-like ethanol drinking in MC3R $\mathrm{R}^{-1-}$ mice. No significant effect of MTII was observed on BEC regardless of genotype. Data are presented as mean \pm SEM. * signifies $p<.05$ relative to vehicle within that genotype. 